Article

\title{
Recharge-Discharge Relations of Groundwater in Volcanic Terrain of Semi-Humid Tropical Highlands of Ethiopia: The Case of Infranz Springs, in the Upper Blue Nile
}

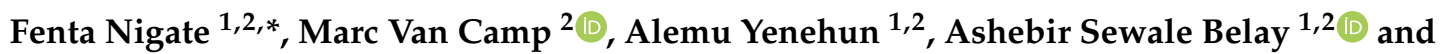 \\ Kristine Walraevens ${ }^{2}$ (D) \\ 1 Blue Nile Water Institute, School of Earth Science, Bahir Dar University, P.O.Box 79, Bahir Dar 6000, Ethiopia; \\ AlemuYenehun.Beyene@ugent.be (A.Y.); AshebirSewale.Belay@ugent.be (A.S.B.) \\ 2 Laboratory for Applied Geology and Hydrogeology, Department of Geology, Ghent University, Krijgslaan \\ 281-S8, 9000 Gent, Belgium; Marc.VanCamp@UGent.be (M.V.C.); Kristine.Walraevens@UGent.be (K.W.) \\ * Correspondence: fentanigate@gmail.com
}

Received: 19 November 2019; Accepted: 9 March 2020; Published: 18 March 2020

\begin{abstract}
The major springs in the Infranz catchment are a significant source of water for Bahir Dar City and nearby villages, while sustaining the Infranz River and the downstream wetlands. The aim of the research was to understand the hydrogeological conditions of these high-discharge springs and the recharge-discharge relations in the Infranz catchment. The Infranz catchment is covered by highly pervious and young quaternary volcanic rocks, consisting of blocky, fractured, and strongly vesicular scoriaceous basalt. At the surface, these rocks crop out as lineaments forming ridges, delimiting closed depressions in which water accumulates during the rainy season without causing surface runoff. Geology and geomorphology thus combine to produce very favorable conditions for groundwater recharge. Three groundwater recharge methods were applied to estimate groundwater recharge and the results were compared. Groundwater recharge was calculated to be $30 \%$ to $51 \%$ of rainfall. Rapid replenishment raises the groundwater level during the rainfall period, followed by a rapid decline during the dry season. Shallow local flow paths discharge at seasonal springs and streams, while more regional and deeper flow systems downstream sustain the high-discharge springs and perennial Infranz River. The uptake of $75 \%$ of spring water for the water supply of Bahir Dar City, local extraction for domestic and small-scale irrigation use from springs, rivers and hand-dug wells, encroaching farming, and overgrazing are exacerbating wetland degradation.
\end{abstract}

Keywords: Infranz River; Bahir Dar; Ethiopia; hydrochemistry; over-extraction; wetland degradation

\section{Introduction}

Groundwater is the major source of fresh water across the globe where human and ecological communities depend on it [1]. Sometimes groundwater can become critical to survival when surface water resources run dry during a severe drought. The dynamics, mainly recharge-discharge conditions of groundwater, are essential for the sustainable use of groundwater which affects groundwater-dependent streams, wetlands, and ecosystems [2]. The recharge-discharge mechanism of groundwater highly differs from place to place and depends on different variables. Groundwater occurrence and dynamics in Ethiopia, specifically in the Tana basin, are complex, which is attributed to the wide heterogeneity of geological, geomorphological, topographical, and hydro-climatic conditions [2,3]. Understanding the controls of the recharge-discharge mechanism of groundwater for a given area is essential for the sustainable use of this precious resource. 
Groundwater recharge can be defined as the percolation of water into the saturated zone [4-7] whereas groundwater discharge is the removal of groundwater from the saturated zone across the water table surface. Hence, quantification of groundwater recharge is of prime importance for the evaluation of groundwater resources [6,8]. The recharge is expected to be high in the wet season, and there is no recharge during the dry seasons, where there is no precipitation.

The Infranz catchment is a small watershed found in the northwestern part of Ethiopia, west of Bahir Dar City (Figure 1). It is one of the sub-catchments in the Lake Tana basin, which drains into the lake. The geology is made up of volcanic rocks, mainly basalts. While most of the Tana basin is covered by Tertiary volcanic rocks, in the Infranz catchment, young, Quaternary, and highly vesicular basalt prevails. Basaltic rocks may vary from impermeable to highly permeable [9], the latter forming excellent aquifers that may be grouped with the most permeable rocks on Earth [10]. The occurrence of the recent Quaternary basalt in the Tana basin is restricted to a rather small part to the south of Lake Tana, including the entire Infranz catchment. The area where the young Quaternary volcanics are present has a distinct landscape. The outcropping volcanic rocks form a gently undulating surface with depressions surrounded by blocky fractured and vesicular basaltic rocks. These almost circular depressions, together with the intrinsic characteristics of the rock (highly porous and permeable due to intensive fracturing, volcanic tubes, interconnected vesicles, and their blocky nature), may be expected to create favourable conditions for the strong infiltration of rainwater during the rainy period. The recent Quaternary and highly porous, permeable basaltic aquifer forms the main aquifer system in the Lake Tana basin [11]. In this regard, the Infranz catchment is a unique watershed in the Lake Tana basin as well as in the Upper Blue Nile basin.

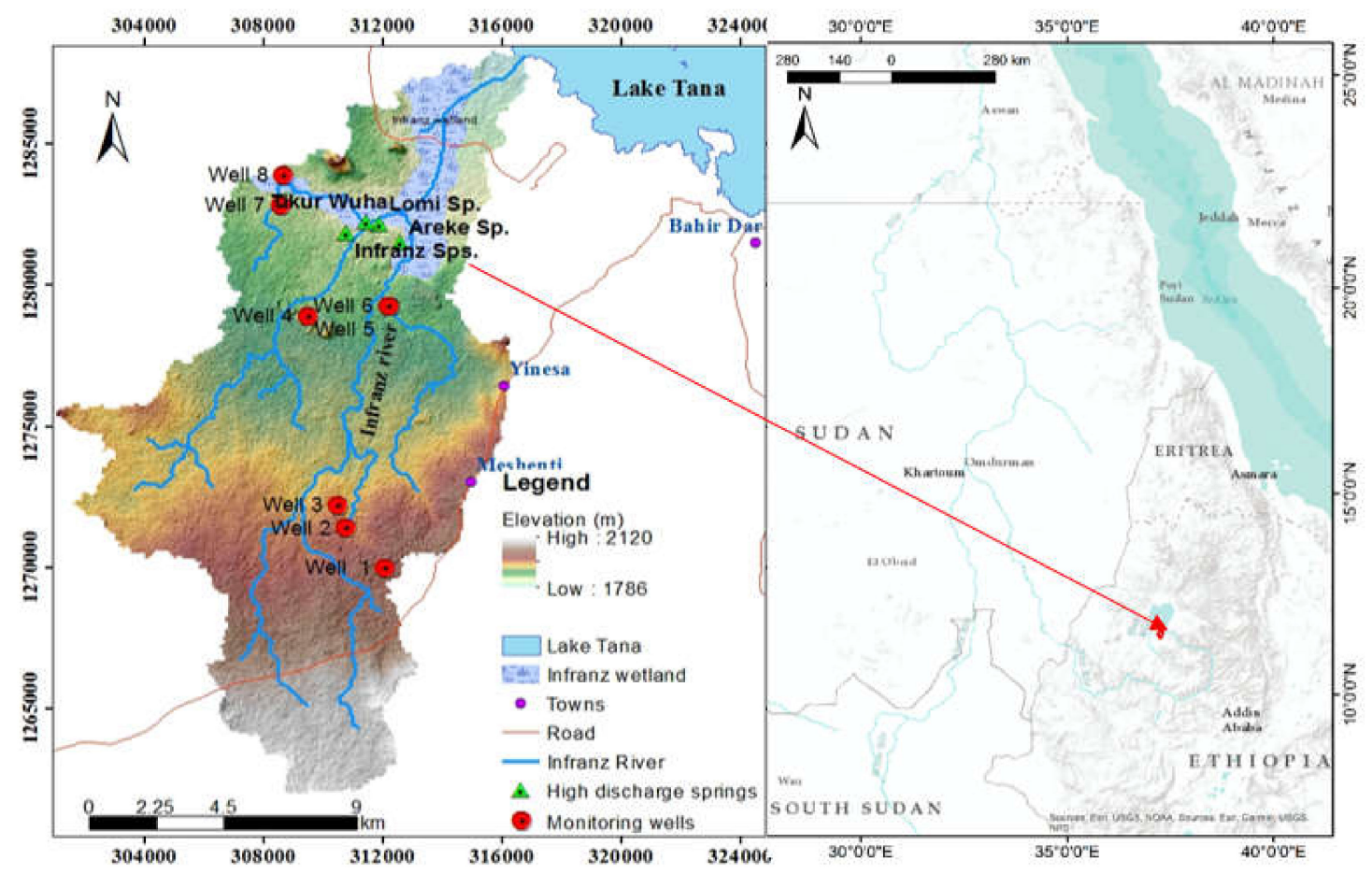

Figure 1. Location map and sampling points of the Infranz catchment, showing high-discharge springs, intermittent springs, and monitoring wells (Well 1-8) in the Infranz catchment.

The Infranz catchment has the unique feature to comprise a series of relatively high-discharge springs: Areke, Lomi, Tikur Wuha, and two Infranz springs. These springs sustain the Infranz River and the downstream wetlands, reaching down to Lake Tana. Studies in other parts of the world indicate that this kind of rock, comparable to the young Quaternary basalt, is highly productive and 
yields high-discharge springs (e.g., [10,12]). Understanding the pertinent hydrogeological system of the catchment is critically important for the sustainable management of these high-discharge springs.

Since 2002, the Areke and Lomi springs have been the main sources of fresh water supply for the fast-growing and expanding metropolitan city of Bahir Dar. The abstraction of water from the Areke and Lomi springs was about $51 \%$ (about $100 \mathrm{~L} / \mathrm{s}$ ) and $49 \%(40 \mathrm{~L} / \mathrm{s}$ ) respectively of their estimated discharge [13]. The rest of the water was leaving the site as an overflow and drained into the wetlands before joining into the Infranz River downstream. The uptake of water from the two springs has been recently increased to $145 \mathrm{~L} / \mathrm{s}$ from Areke and $63 \mathrm{~L} / \mathrm{s}$ from the Lomi spring, resulting in the diversion of some $75 \%$ of discharge of both springs, as calculated from the estimated discharge by [13] and the uptake of water by the city water supply. Currently, Infranz springs are constructed for water supply for Bahir Dar City.

Other high-discharge springs are emerging at springs at the foot of the Choke shield volcanic mountain (outside the study area), such as the Bure Baguna, Andasa, and Jiga springs. Choke Mountain is a regional shield volcano, which is characterized by large networks of deep-running tectonic discontinuities [14]. The springs are recharged through these discontinuities, from outside their local catchment [14]. The Areke, Lomi, Tikur Wuha, and Infranz twin springs are situated to the north of Choke Mountain, and these springs were inferred to receive recharge in a comparable way also [14]. However, [13] reported that these are depression springs. The regional study undertaken by [15], based on hydrochemical and isotopic data, points to the source of these spring waters being from local rather than from regional origin, and that the springs are emerging at the point of contact of the Quaternary basalt and the less permeable underlying Tertiary rhyolitic rock (part of Trap Series Formation).

Even though the catchment is the source of the water supply, the groundwater recharge of this catchment is poorly studied. However, an accurate estimation of groundwater recharge is important to assess the hydrological system of the catchment. The demand to quantify groundwater replenishment to the aquifer system is increasing and has become crucial for water resource management.

In the entire Lake Tana basin, where the Infranz catchment is located, few regional and local hydrogeological, hydrochemical, and isotopic hydrology studies and recharge estimations were undertaken $[10,15-26]$. Some studies have been conducted on groundwater recharge estimation using different recharge estimation methods $[16-18,26]$. However, the recharge may be spatially variable and can be largely influenced by geological conditions. The Infranz catchment has special geological and geomorphological characteristics, which differentiates it from the overall Lake Tana basin.

In this study, three recharge estimation methods-chloride mass balance (CMB), soil water balance (SWB), and water table fluctuation (WTF) have been used to estimate the groundwater recharge of Infranz catchment.

The purpose of this study was to assess groundwater recharge-discharge conditions in volcanic rock formations with particular emphasis on young Quaternary highly vesicular basalt, and to understand the hydrogeological settings of the major springs of the Infranz catchment. Finally, the development of a conceptual groundwater flow model is also an important objective.

\section{Description of the Study Area}

\subsection{Location and Climate of the Study Area}

The Infranz catchment is part of the Lake Tana basin in north-eastern Ethiopia, Amhara region. The catchment is situated to the south of Lake Tana, which is known as the source of the Blue Nile. The climate of the Lake Tana basin is categorized as a temperate climate. However, some parts are sub-tropical to sub-afro-alpine. The rainfall season mainly extends from June to September. The annual average precipitation of Bahir Dar area is estimated at $1415 \mathrm{~mm}$. The air temperature varies from place to place, with an annual average of about $20^{\circ} \mathrm{C}$ [27]. At Bahir Dar Station (which is the nearest meteorological station to the study area), the annual daily maximum temperature is about $27^{\circ} \mathrm{C}$, while the daily minimum is $13^{\circ} \mathrm{C}$. 


\subsection{Geology and Hydrogeology of the Study Area}

The Lake Tana basin, in which the study area is situated, comprises three types of geologic units: (1) Trap Series (Oligocene to Miocene) volcanic flows and edifices mainly found in the highlands and escarpments. The Trap Series geologic unit encompasses Ashange, Aiba, Alaje, and Tarmaber basalt; (2) Quaternary basalt locally found in the lowlands of the basin (old Quaternary and recent Quaternary), and occurring to the south of the lake particularly, including the Infranz catchment; and (3) Quaternary sediments that comprise alluvial lake deposits that are found in the floodplain of major rivers and at the shore of Lake Tana [25,28-31].

The geology of the Infranz catchment was studied in detail by field mapping during several campaigns between 2013 and 2018. The geology was linked to the specific landscape of the catchment, as observed in the field (documented by photographs) and on Google Earth. A geological cross-section has been established.

The recent Quaternary lava flows form vesicular and highly pervious basalts, attributing a high hydraulic conductivity to them. This can even be increased at the surface by slight weathering, as observed in the field. This hydrogeologic unit comprises two types of porosity: primary porosity, which is related to the vesicles, and secondary porosity, which is related to the fractures and fissures. In this formation, large and small volcanic tubes are common. This contributes relatively high transmissivity and storage capacity to the formation. Generally, the transmissivity of Quaternary basalts is high and varies from 100-200 $\mathrm{m}^{2} /$ day [32]. Most of the boreholes drilled in the recent Quaternary basalt unit mainly yield more than $20 \mathrm{~L} / \mathrm{s}$ [19].

A group of important springs is emerging from this recent Quaternary basalt in the Infranz catchment (Figure 1). The discharges of the Areke and Lomi springs are estimated by [13] to be $210 \mathrm{~L} / \mathrm{s}$ and $90 \mathrm{~L} / \mathrm{s}$, respectively. The Tikur wuha spring discharges more than $40 \mathrm{~L} / \mathrm{s}$ [19]; the Infranz twin springs have a discharge of more than $60 \mathrm{~L} / \mathrm{s}$ [19]. In addition to these high-discharge springs, there are other low discharges and intermittent springs emerging in the same formation.

The occurrences and appearances of the springs are assumed to be linked to the contact with the underlying old Quaternary basalt and less pervious Tertiary rhyolitic formations that are mapped in the spring area [24].

The Infranz wetland is found immediately downstream from the springs and stretches to the river mouth at Lake Tana. This wetland is formed by groundwater seepage and outflows of water from springs before joining the Infranz River and is sustained by the river discharge. However, this wetland is becoming degraded as it is drying up, due to most of the spring water being taken away, leading to encroaching farming and overgrazing.

Since groundwater recharge is from the entire catchment, the water chemistry may be influenced by activities in the whole catchment area. The concentration of specific constituents of the water chemistry is also influenced by the length of the flow path or residence time in contact with the various rock types, along with anthropogenic activities.

The geological setting of the Infranz catchment was assessed based on drilling descriptions and field observations. This information was included in the geological map. The hydrogeological conditions of the springs and wetlands were deduced on this basis, and are presented in a cross-section, showing the conceptual model of groundwater flow in the catchment.

\section{Materials and Methods}

\subsection{Data Collection}

To understand the hydrologic situation and sources of water for the wetland, different field campaigns were conducted in and around the Infranz catchment. The field trips were performed in 2013 and 2015 to 2018 in all seasons: the dry season, (February to May), slightly wet season (September to January), and wet season (June to August). While conducting the fieldwork, spring inventories were set up in accessible areas. Monitoring wells were selected based on accessibility, geology, and 
physiography. Key informant interviews with local people were undertaken by questioning them about the wetland, stream and spring conditions, and how the wetland conditions are changing with time, and if they have observed informal encroaching farming affecting the wetland system. In different field campaigns, we tried to explore the intermittent streams upstream and perennial streams downstream with reference to the emerging point of the high-discharge springs (Areke, Lomi, Tikur Wuha, and Infranz) and the change of spring discharge with time. The first author was part of the group involved in a wetland restoration study conducted in 2012. During repeated field works, hand-dug wells were dug to study the interaction of the wetlands and the shallow groundwater. On the basis of field observations of geology and geomorphology, informant interviews, and existing geological and hydrogeological maps and interpretation of Google Earth satellite images, we tried to investigate the hydrological system of the catchment. The riverine system of the Infranz catchment was investigated and the sources of water in the river system and wetlands were studied. Based on these field observations, the geological map of the area was compiled, as a prerequisite for understanding groundwater recharge in the specific conditions of the Infranz catchment, which are in contrast to the regional conditions of Tana basin.

Meteorological data from 2012-2016 have been collected from Bahir Dar Meteorological Station, which is a first-order meteorological station providing minimum and maximum temperature, wind speed, relative humidity, and sunshine hours. These data were used to estimate groundwater recharge by using three methods.

Groundwater samples in the catchment and rainwater samples (in and around the catchment) were collected in different years (from 2015-2016) to determine chloride concentration. Water samples for chemical analysis were collected in clean polyethene bottles and the bottles were rinsed three times with the sample water before being filled. The analysis of the water samples was carried out at the water chemistry lab of the Laboratory for Applied Geology and Hydrogeology, Ghent University, Belgium. The limit of detection of chloride concentration was $0.1 \mathrm{mg} / \mathrm{L}$. Before using the water chemistry data, we tested the ionic balance of the major ions, and the error on the ionic balance is less than $5 \%$.

\subsection{Groundwater Flow System and Groundwater Level Monitoring}

Three groundwater flow systems were identified in a small basin: local, intermediate, and regional [33]. The groundwater system of a basin is mainly influenced by soil type, hydrology, hydrogeological condition, and topography in recharge areas (upland areas) and discharge areas, such as wetlands, springs, and rivers. Physical observations related to natural groundwater flow and well logging data were used to infer the local and regional flow of the catchment scale. On this basis, we tried to outline the local and regional flow lines in the Infranz catchment.

To understand the groundwater flow system of the Infranz catchment, shallow groundwater-level measurements were conducted in eight community-owned hand-dug wells. The measurement was conducted weekly and, occasionally, bi-weekly between 10/05/2016-6/03/2017 by electric sensor water level meters. The monitoring wells were selected based on the hydrogeomorphic and geologic situation and accessibility (Figure 1).

\subsection{Groundwater Recharge Estimation}

Groundwater recharge is defined as the downward movement of water reaching the water table, joining to the groundwater reservoir [4-6,34,35]. Even though there is an evident uncertainty with current recharge estimation methods, accurate recharge estimation is still important $[36,37]$ in water resources studies. To estimate groundwater recharge, three commonly used and globally accepted estimation techniques were applied to increase the reliability of the estimation and the results were compared. Each method is explained in detail in the following sub-sections. 


\subsubsection{Groundwater Recharge Estimation by Chloride Mass Balance (CMB) Method}

The chloride mass mass-balance method was developed by [38]. It compares chloride in precipitation with chloride in groundwater, in which recharge from precipitation is the only source of chloride [39]. The increased chloride in groundwater is attributed to evapo-concentration. To calculate the chloride mass balance for recharge estimation, water samples were collected from springs and rainwater. With the assumptions that chloride is a conservative tracer, that the source of chloride ions in the soil zone or groundwater is from precipitation, and that no recycling or concentration of chloride within the aquifer occurs [36], it is possible to use the following formula to estimate a spatially averaged recharge flux to the aquifer [8,36-39]:

$$
\mathrm{R}=\mathrm{P} \times \mathrm{Cl}_{\mathrm{p}} / \mathrm{Cl}_{\mathrm{gw}}
$$

where $\mathrm{P}$ is the mean annual effective precipitation in $\mathrm{mm}$ (annual precipitation-surface runoff), $\mathrm{R}$ is total annual recharge $(\mathrm{mm}), \mathrm{Cl}_{\mathrm{p}}$ is the mean chloride concentration in precipitation $(\mathrm{mg} / \mathrm{L})$, and $\mathrm{Cl}_{\mathrm{gw}}$ is the chloride concentration in shallow groundwater $(\mathrm{mg} / \mathrm{L})$. The chloride ion is used in chemical recharge studies because of its conservative nature, not being leached from or adsorbed by the soil [39].

Groundwater recharge to the regional system was estimated based on chloride concentration of eight rainwater samples and 18 groundwater samples. The low chloride concentrations found in the sampled springs provide confidence in the absence of other sources of chloride.

Chloride concentrations from eight rainfall samples and 18 groundwater samples, all taken in $2015 / 2016$, were used. The groundwater samples were fairly distributed spatially, and the rainfall was sampled at different months of the rainy season to account for the possible temporal variation of rainfall composition.

\subsubsection{Groundwater Recharge Estimation by Soil Moisture Balance (SMB) Method}

Estimation of recharge in a variety of climatic conditions is possible using a daily soil moisture balance based on a single soil store [40]. The method was first developed by [41] and later was applied for estimating the groundwater recharge of different studies (e.g., [40,42-46]).

In this method, groundwater recharge is calculated on a daily time scale by the following formula:

$$
\mathrm{R}=\mathrm{P}-\mathrm{PET}-\text { Runoff }-\Delta \mathrm{SM}
$$

where $\Delta \mathrm{SM}$ is the difference between soil moisture content (SM) of the calculated and preceding day, which is zero if the moisture content remains at field capacity, i.e., SM on both days would be equal to the plant available water (PAW) value, usually in the wet season. P, PET and Runoff are the daily precipitation, potential evapotranspiration, and overland flow, respectively.

The PET is estimated using the meteorological data of the nearby Bahir Dar Meteorological Station. The Penman-Monteith formula modified by [47] was used to calculate daily PET. Precipitation data of the Bahir Dar Meteorological Station were used. There was no river discharge monitoring station on the Infranz River. Hence, the surface runoff was estimated based on expert judgement, i.e., by taking the geological, topographical, and human activity factors into account. The PAW was estimated using the hydraulic properties calculator (SPAW) computer program developed by USDA and Washington State University in cooperation in 2006, and later revised in April 2019. In addition, the table of [41] reporting PAW values for different possible land use and soil combinations was consulted for refining the estimated value. 


\subsubsection{Groundwater Recharge Estimation by Water Table Fluctuation (WTF) Method}

Groundwater recharge estimation based on groundwater level data is among the most widely applied techniques [48]. The method has been applied by many researchers (e.g., [46,48-50]). The effectiveness of the technique highly depends on how close the assumptions of the method are met, and how accurate the estimation of the specific yield is. The principle behind the WTF method is that the water level rise is caused only by precipitation. The WTF method works well with the assumption that the aquifer shows sharp water level rises and declines, respectively, for the presence and absence of precipitation. The aquifer system needs to be unconfined with a shallow water table, otherwise it may not display sharp rises because wetting fronts tend to disperse over long distances [48]. The influence of pumping is null so that the fluctuations are only attributed to rainfall events.

The groundwater recharge is calculated by the following formula:

$$
\text { Recharge }=\operatorname{Sy} \frac{\Delta \mathrm{h}}{\Delta \mathrm{t}}
$$

where $\Delta \mathrm{h}=$ the head change through the recharging period; $S y=$ is the specific yield, and $\Delta t=$ is the recharging time period.

\section{Results and Discussion}

\subsection{Geology of the Infranz Catchment}

In the Infranz catchment, the Tertiary volcanics are largely covered by Quaternary volcanics, particularly by young Quaternary volcanic rocks (Figure 2). The Alaji formation, part of the Tertiary Trap Series formation, is exposed near to the major springs area. This formation mainly consists of flood basalts associated with rhyolite and subordinate trachyte plugs that contain transitional to tholeiitic basalts [24]. Rhyolite was outcropping near the major springs area. The Tertiary volcanics have relatively modest average permeability.

The old Quaternary volcanic rock is exposed in the eastern part of the catchment at the Meshenti area. It consists of olivine basalts and subordinate phonolitic lavas and it covers much of the southern Tana basin [51], as cited in [52]. The aphanitic basalt is dark grey to black, fine-grained, and compacted rock. The old Quaternary basalt is mainly composed of $60 \%$ plagioclase, $30 \%$ pyroxene, $8 \%$ opaque minerals, and $2 \%$ olivine [24].

The young Quaternary volcanic rocks in the Infranz catchment are characterized as scoriaceous basalt flows: dark gray to greenish-gray, strongly vesicular to scoriaceous, porphyritic olivine, pyroxene-plagioclase, zeolite-rich phyric, thin basalt flows. They are mainly composed of $50 \%$ plagioclase, $20 \%$ pyroxene, $15 \%$ opaque minerals, and $15 \%$ olivine [24]. They are scarcely weathered and it is possible to recognize the original "pahoehoe" and "aa" lava flow structures.

The basalts are highly vesicular, with rounded to elongated vesicles, filled, in most cases, by zeolites, calcite, quartz, or chalcedony amygdales of up to $6 \mathrm{~cm}$ diameter, that show strong alignment or elongation parallel to the flow layering (Figure 3). They show narrow to large volcanic tubes as observed around the springs at outcrop and cuts from quarries in the Merawi area. Scoria cones are also associated with this rock unit (Figure 4). 


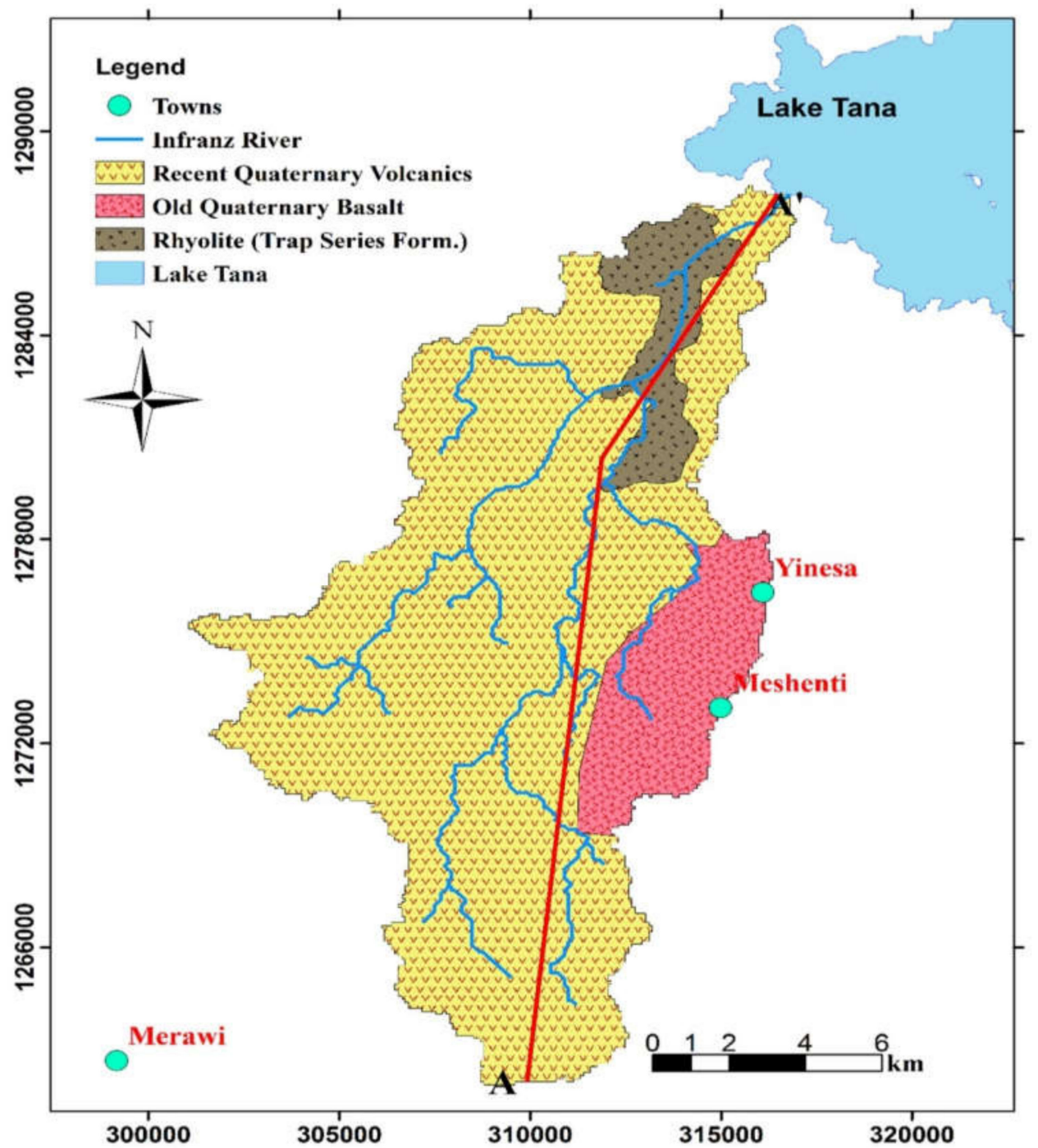

Figure 2. Geological map of the Infranz catchment and location of the cross-section (the red line passes through $\mathrm{A}-\mathrm{A}^{\prime}$ is showing a cross-section line).
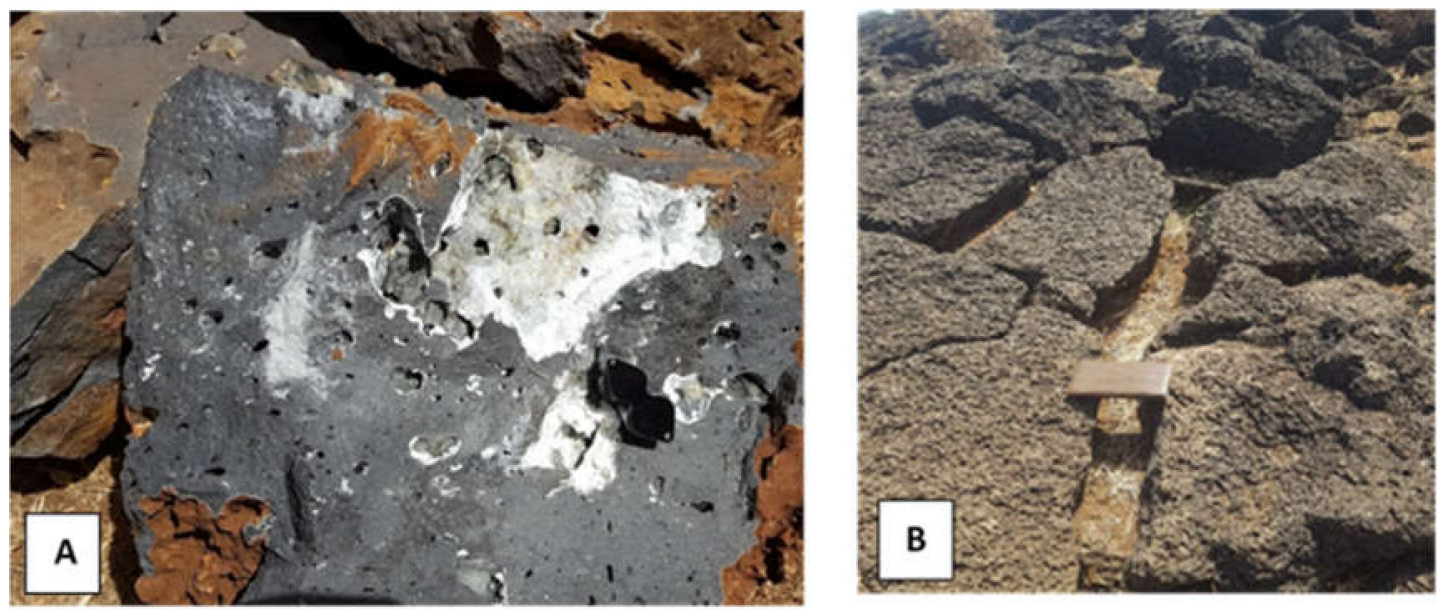

Figure 3. (A) Young Quaternary rock with vesicles filled in by zeolites, calcite, quartz, or chalcedony amygdales; (B) Blocky fractured vesicular basalt which forms undulating geomorphology. 

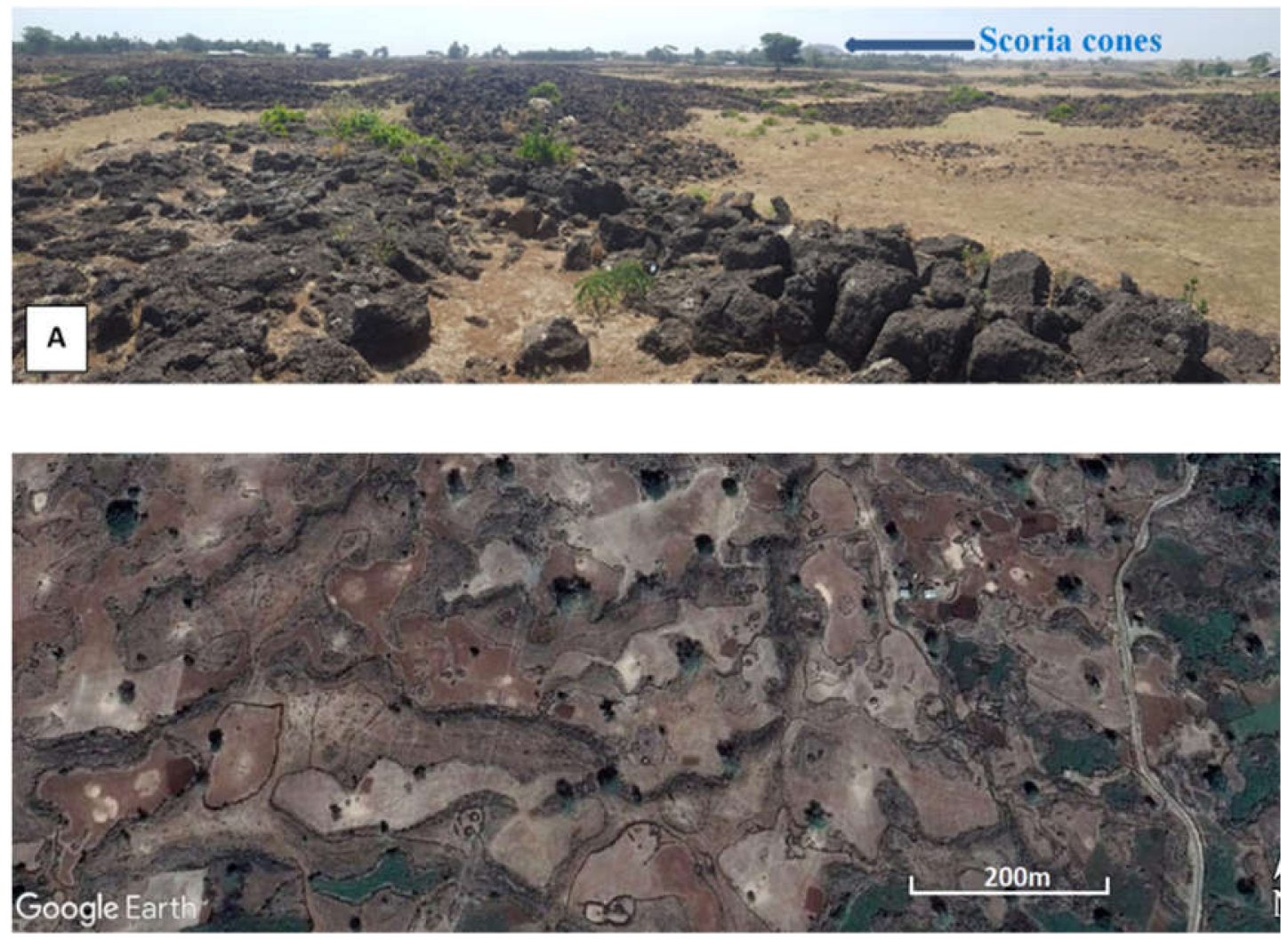

Figure 4. Young Quaternary volcanic rock unit forming a gently undulating plain which creates depressions surrounded by blocky fractured rocks; (A) field photo and (B) Google Earth image (February 13, 2018). 37P: 311954.76, 1281626.29 N, eye alt, 3.31 km, Image@2019 CNES/Airbus. https://www.google.com/maps/@11.58995,37.279,7096m/data=!3m1!1e3.

The Quaternary basalts are highly jointed and fractured, forming blocky to ball-shaped vesicular flows, commonly known as pillow lava (Figure 4), flowing out of fissures. The joints and fractures develop during cooling. They are vertical to sub-vertical with dominant N-S direction, while two subsidiary sets are orientated NE-SW and NW-SE. The dominant N-S orientated joints are manifestations of the regional fault direction (extension of the N-S orientated Tana graben), which defines the weakness direction along which the basaltic lava flows likely erupted through fissures. The interconnection of the vesicles combined with fractures developed in the unit, as well as its inherent scoriaceous nature, result in high porosity and permeability along with vesicles, joints, and fractures.

Most parts of this young Quaternary volcanic rock unit form a gently undulating plain, with a typical landscape of closed depressions surrounded by the lineaments of blocky fractured rocks (Figure 4A). This is clearly visible on Google Earth (Figure 4B). The depressions are covered by thin alluvial deposits whereas the blocky fractured bare rock lineaments surround the depressions. The geomorphology causes a collection of water in the closed depressions during the rainy season, preventing surface run-off and favoring infiltration to the groundwater

\subsection{Springs Occurrence and Relationship with the Wetland System}

The surface geology of the area is made up of highly porous and permeable vesicular basalt, which has scoriaceous contact zones of individual local lava flows. This provides access to conduits for rapid local and regional (at catchment scale) flow. The five major springs, along with other smaller springs which are situated approximately $8 \mathrm{~km}$ west of Bahir Dar, discharge from these vesicular and highly fractured basalts. On one hand, intermittent springs and wetlands can be observed, whereas on the other hand, high-discharge springs and the perennial river occur, as shown in Figure 5. Streams 
upstream of the major spring zone show low flows and run dry during the dry season. Wetlands upstream of the major spring zone are also seasonal, becoming dry in the dry season.

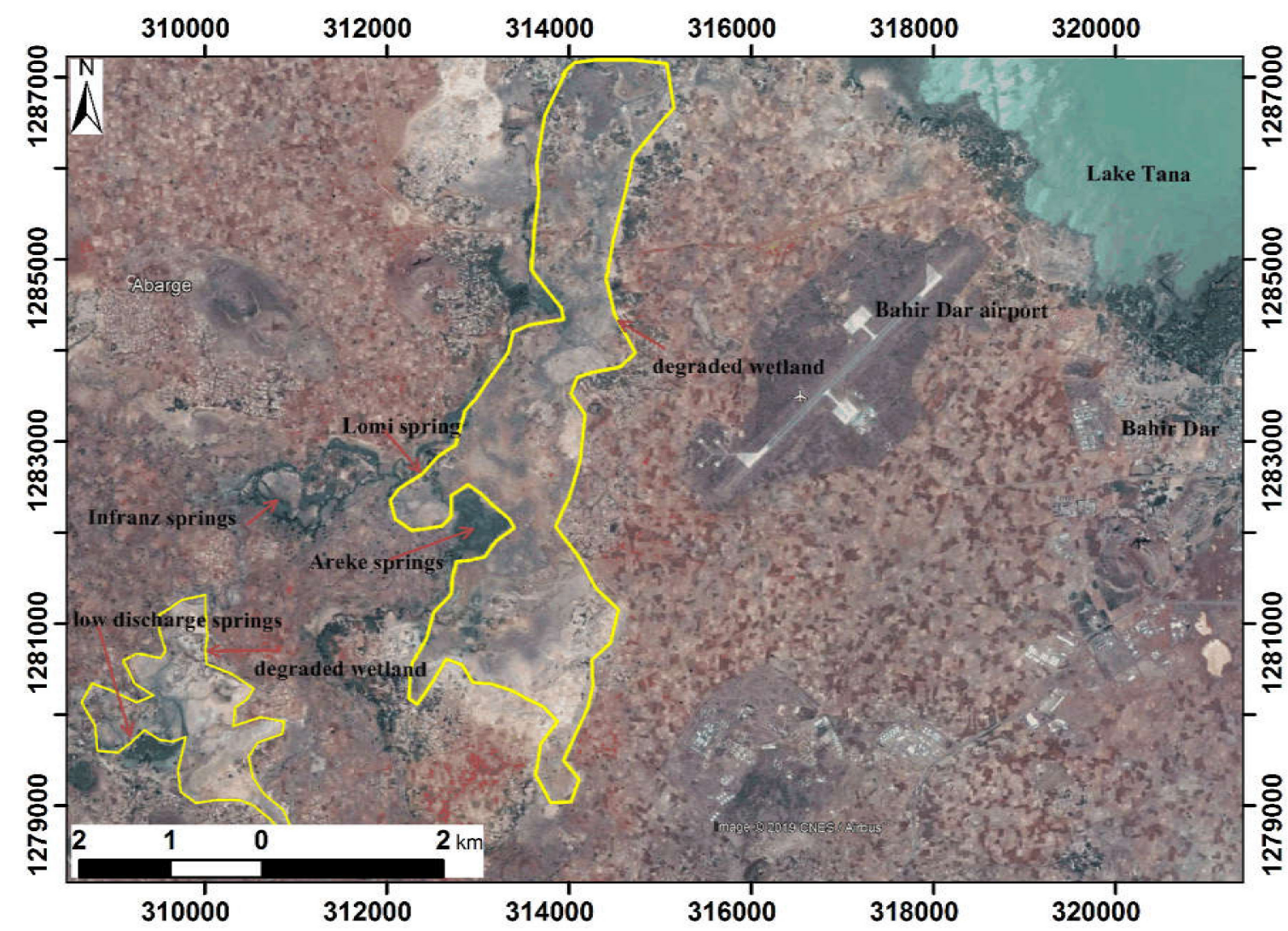

Figure 5. Map showing wetland areas in the dry season and dried wetlands (Google Earth Pro image of March 23, 2013, 37P: 316279.39 E, 1283918.30 N, eye alt, 19.23 km, Image@2019 CNES/Airbus, https://www.google.com/maps/@11.60951,37.31492,28383m/data=!3m1!1e3), yellow lines representing boundaries of wetlands.

From the conducted field work and random interviews with local people (2013 and 2015 to 2018), it was clear that some streams, seepage zones, and some of the low discharge springs are drying up in the dry season, though these are the sources of water to wetlands during the wet season, and that these conditions have worsened with time. The water withdrawal from the high-discharge springs results in reduced outflow to the downstream wetlands and lower flow in downstream Infranz River to the lake. The local people also confirmed that before the extraction of water for water supply (2002), the wetland was sustained throughout the year, especially around the high-discharge springs, with no access possible for farming nor grazing. It was assessed by [53] that the areal coverage of the Infranz wetlands had decreased to $34 \%$ in the year 2011. They confirmed, as we have witnessed, that the wetlands now become dry in the dry season and this encourages local farmers to encroach the wetland with farming (Figure 5).

\subsection{Groundwater Level Monitoring}

The aquifer storage is affected by the addition or extraction of water from the aquifer. This, in turn, causes groundwater level fluctuations. Figure 6 shows the response of shallow groundwater to precipitation. During the rainfall months (June, July, and August), the water level rises and reaches a maximum level in July. All the wells instantaneously respond to the start of the rainfall period due to rapid recharge and reaching the maximum in July, staying somewhat constant till halfway through September, where they then start to drop at the end of the rainfall period (Figure 6). The small peak 
(Figure 6) in the month of February is related to limited rainfall in winter, which is not very common in the area. During the dry season, the water table has a relatively large depth in the upstream sections at high elevation (reaching down to $15 \mathrm{~m}$ depth in the most upstream Well 1), while depth is smaller in downstream wells (around $2 \mathrm{~m}$ depth in most downstream Well 4). This is due to elevation variations. The rise during the rainy season is the largest in the upstream sections, reaching $8 \mathrm{~m}$ amplitude in Well 1 while being restricted in downstream sections (less than $2 \mathrm{~m}$ amplitude in Well 6). In the rainy season, the water level may reach up to the surface in the downstream part (overflowing in Well 6), while in most upstream, well 1, the water table is still at $7 \mathrm{~m}$ depth. The steep rise in the upstream wells indicates fast and important groundwater recharge. This increases the volume of water stored in the aquifer. The recession is also relatively steep in the higher parts due to groundwater draining from elevated to lowland areas due to gradient variations, which decreases the groundwater storage from the aquifer. Wells in the lowlands show minimum fluctuations and stay almost stable throughout the year.

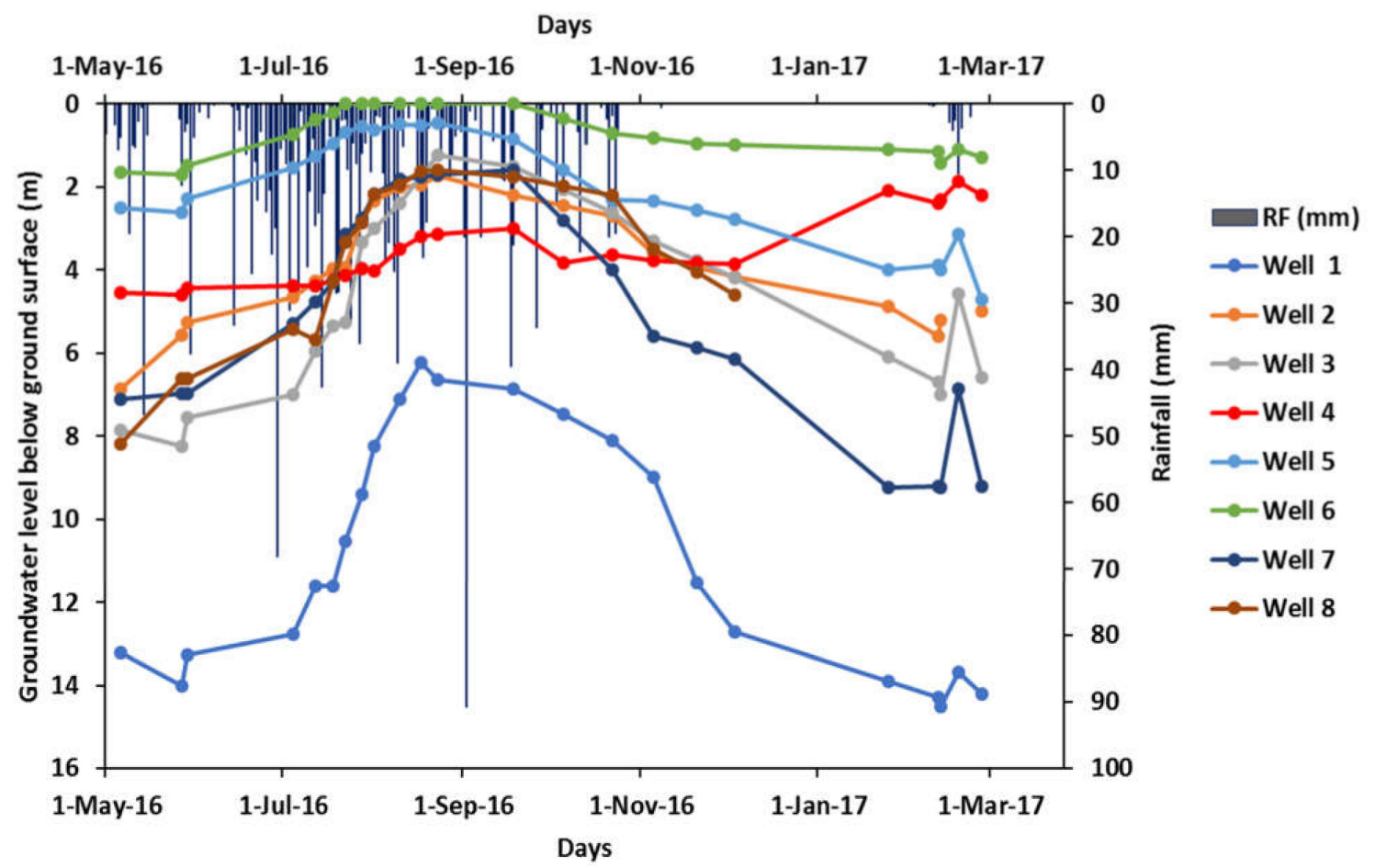

Figure 6. Groundwater level fluctuation within the Infranz catchment in response to the wet and dry season, with an indication of daily rainfall (the striking peaks in February were registered on 18/02/2017).

\subsection{Groundwater Recharge}

\subsubsection{Groundwater Recharge from Chloride Mass Balance (CMB) Method}

The rainfall in Bahir Dar shows chloride concentrations varying from $<0.1 \mathrm{mg} / \mathrm{L}$ to $4 \mathrm{mg} / \mathrm{L}$ whereas the concentrations of the high-discharge spring water samples vary from $0.3 \mathrm{mg} / \mathrm{L}$ to $12.5 \mathrm{mg} / \mathrm{L}$. For the calculation of recharge by the CMB method, we used the average concentration of the rainwater samples $(\sim 1.8 \mathrm{mg} / \mathrm{L})$ and groundwater samples $(\sim 6.1 \mathrm{mg} / \mathrm{L})$. Chloride concentrations from eight rainfall samples and eighteen groundwater samples, all taken in 2015/2016, were used. The groundwater samples were fairly distributed spatially, and the rainfall was sampled at different months of the rainy season to account for the possible temporal variation of rainfall composition. The correlation between nitrate and chloride was checked beforehand to eliminate pollution, and they were not correlated (Figure 7). This provides confidence that chloride in the groundwater is from rainfall only, and that the 
$\mathrm{CMB}$ method is applicable. The mean value of $\mathrm{Cl}$ concentration in rainfall $(4.6 \mathrm{mg} / \mathrm{L})$ in Abu Delige in Sudan [54] is higher than the mean value of $\mathrm{Cl}$ in precipitation of our study area (the former location being near to the coast) but comparable with the mean value $(2.88 \mathrm{mg} / \mathrm{L})$ found at Sahl, Senegal [55]. The mean of $\mathrm{Cl}$ from rainfall samples from Addis Ababa is about $0.95 \mathrm{mg} / \mathrm{L}$ [8], which might be due to the location being far from the coast and with low atmospheric dust. Yearly precipitation from Bahir Dar Meteorological Station is $1467 \mathrm{~mm}$ (based on the measuring period 2012-2016). The area is typically characterized by many closed depressions floored and surrounded by the highly permeable open jointed basaltic rocks, with a very thin soil covering some of the depressions' floors. The slope is generally flat to very gentle in between the low ridges of blocky volcanic rocks, where the closed depressions collect the rainwater, and ponding during the wet season may occur. The land use is predominantly bush and shrub type, with a small part of agricultural land. Considering all these physical characteristics of the catchment, we concluded that the surface runoff following rainfall events is negligible, and hence the runoff is set to $0 \mathrm{~mm}$. The effective precipitation is $1467 \mathrm{~mm} /$ year. With these values, the recharge is estimated using CMB to be $436 \mathrm{~mm} /$ year or about $30 \%$ of the annual rainfall. With the approximate surface area of the catchment $\left(\sim 200 \mathrm{~km}^{2}\right)$, this results in recharge of $87.2 * 10^{6} \mathrm{~m}^{3}$ or $\sim 2765 \mathrm{~L} / \mathrm{s}$. This is approximately the total groundwater recharge in the entire catchment based on the CMB method. The high-discharge springs are then discharging about $14 \%$ of this total recharge. Even if the recharge was only $10 \%$ of rainfall (minimum estimate of [56] instead of $30 \%$, the recharge would still largely exceed discharge of all perennial springs approximately by $400 \mathrm{~L} / \mathrm{s}$. The groundwater recharge was also estimated in a nearby area (Dangila district) by using different recharge estimation methods [57], and results were found ranging between 280-430 $\mathrm{mm} /$ year [58]. Based on hydrograph separation, [26] we estimated an average annual recharge of $195.6 \mathrm{~mm}$ over the entire Lake Tana basin. Another study undertaken east of the Infranz catchment, in the Rib catchment, estimated groundwater recharge to be $154 \mathrm{~mm} /$ year based on the CMB method.

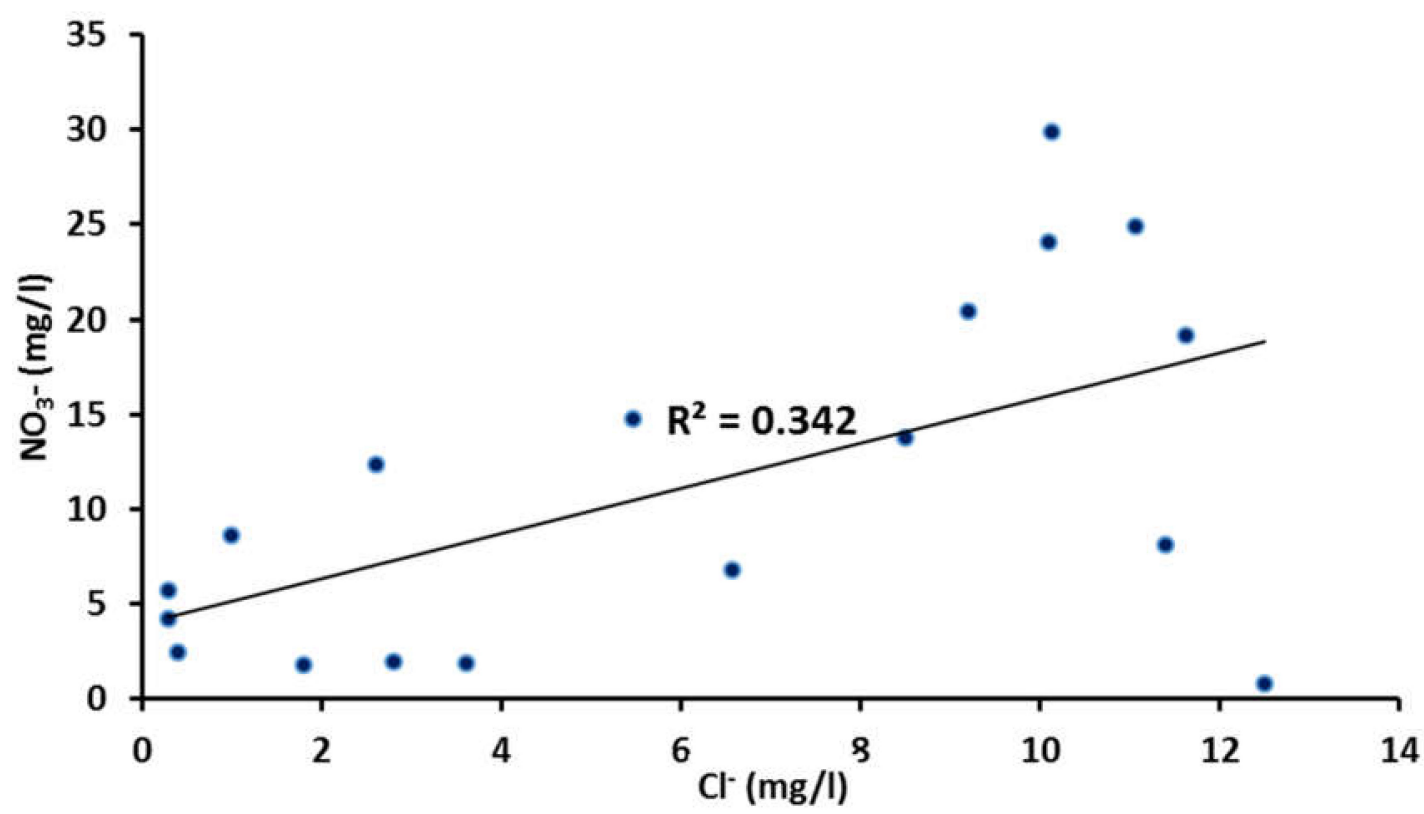

Figure 7. Chloride concentration versus nitrate concentration of the groundwater samples used for the Chloride Mass Balance $(\mathrm{CMB})$ method. The small correlation coefficient value $(\mathrm{R} 2=0.34)$ shows the insignificant pollution effect in the analyzed chloride concentration values.

\subsubsection{Groundwater Recharge from Soil Moisture Balance (SMB) Method}

The daily PET is calculated starting from January 2012 to January 2016 using the Penman-Monteith formula. The daily average value was $4.06 \mathrm{~mm} /$ day. The daily rainfall depth recorded at the Bahir Dar Meteorological Station for the same period was used; it has a mean annual value of $1467 \mathrm{~mm}$. 
The runoff percentage (surface runoff over precipitation) is one of the input factors of the SMB method and is set to 0 . The hydraulic properties calculator (SPAW computer program) supported with the table in [41], in which PAW values for land use and soil combinations are compiled, is used to deduce PAW; a value of $200 \mathrm{~mm}$ was adopted. Since the rainfall season is preceded by a long dry period, the thin soil covering the area would be close to dry. Therefore, the initial soil moisture content (which has very small control over the calculated annual recharge value) is set to $0.5 \mathrm{~mm}$.

The mean annual recharge calculated for the five years (2012-2016) with SMB method amounts to $748 \mathrm{~mm}$, or $51 \%$ of rainfall. In other words, $150 * 10^{6} \mathrm{~m}^{3}$ of water is annually recharging the whole Infranz river catchment. The high-discharge springs only discharge some $8 \%$ of this total recharge. Groundwater recharge is mostly taking place during the main rainy season (Figure 8), while the yearly rainfall is consumed by the plants to satisfy their evapotranspiration and growth demand and to bring soil moisture content up to field capacity. The annual actual evapotranspiration is $638 \mathrm{~mm}$, which is $56 \%$ of annual potential evapotranspiration and $42 \%$ of yearly rainfall.

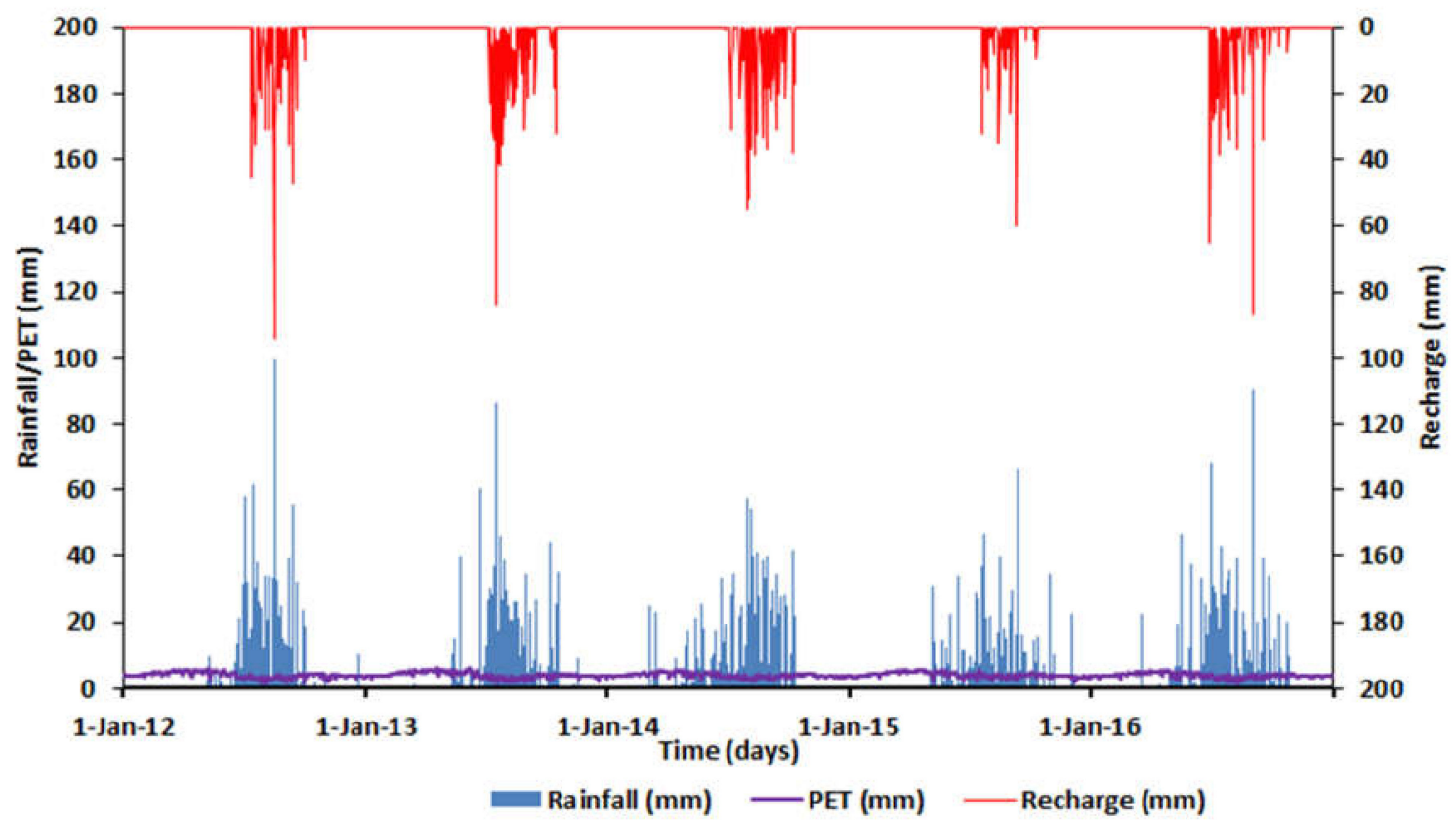

Figure 8. Daily rainfall (Bahir Dar Meteorological Station), potential evapotranspiration (PET) and calculated groundwater recharge (Soil Moisture Balance-SMB method) for the period 2012-2016.

\subsubsection{Groundwater Recharge Estimation by Water Table Fluctuation (WTF) Method}

Based on hydrogeochemical and isotopic hydrological data, previous studies on the Lake Tana basin show that there is no/limited groundwater-lake water interaction [20,21]. Recharge is expected to be dominant in the upstream reaches. Therefore, the groundwater rise in the most upstream well (Well 1) was considered. The seasonal rise of the water table in this well was observed to be $8 \mathrm{~m}$, for the yearly recharge period. Appropriate values of specific yield are difficult to assess for magmatic rocks [59]. The values of specific yield for the volcanic aquifers of Jeju Island was found to be mostly lying within the range of $5 \%-10 \%$ [60]. This range is similar to the range reported by $[57,61]$ for mafic to intermediate volcanic aquifers. Using this range allows us to express uncertainty [59]. With this range of specific yield values, we obtained recharge values between 400 and $800 \mathrm{~mm} /$ year, corresponding to the range covered by recharge obtained with the SMB and CMB methods.

Groundwater recharge was estimated elsewhere in the central and northern highlands of Ethiopia, where the study area is situated, by the water balance method, discharge analysis, and chloride mass balance method at about 10\%-20\% [56]. A similar study by [8] in a tropical highland climate in central Ethiopia using the CMB method estimated the groundwater recharge at $25 \%$ of the annual effective 
precipitation. The high values ranging from $33 \%$ to $51 \%$ we found in this study are due to the specific geological conditions of the Infranz catchment, with the highly vesicular and fractured scoriaceous young Quaternary basalts, and the typical geomorphology with the closed depressions surrounded by the low basalt ridges.

Figure 9 shows the results of the three different recharge calculating methods. Recharge estimated by SMB is higher than the other two methods (CMB and WTF). The reason for this could be that SMB calculates potential recharge without considering the limit of aquifer storage, whereas both of the other methods calculate the 'actual recharge'. The lower part of the Infranz catchment is expected to be storage controlled (because of water table near to ground surface) rather than precipitation controlled.

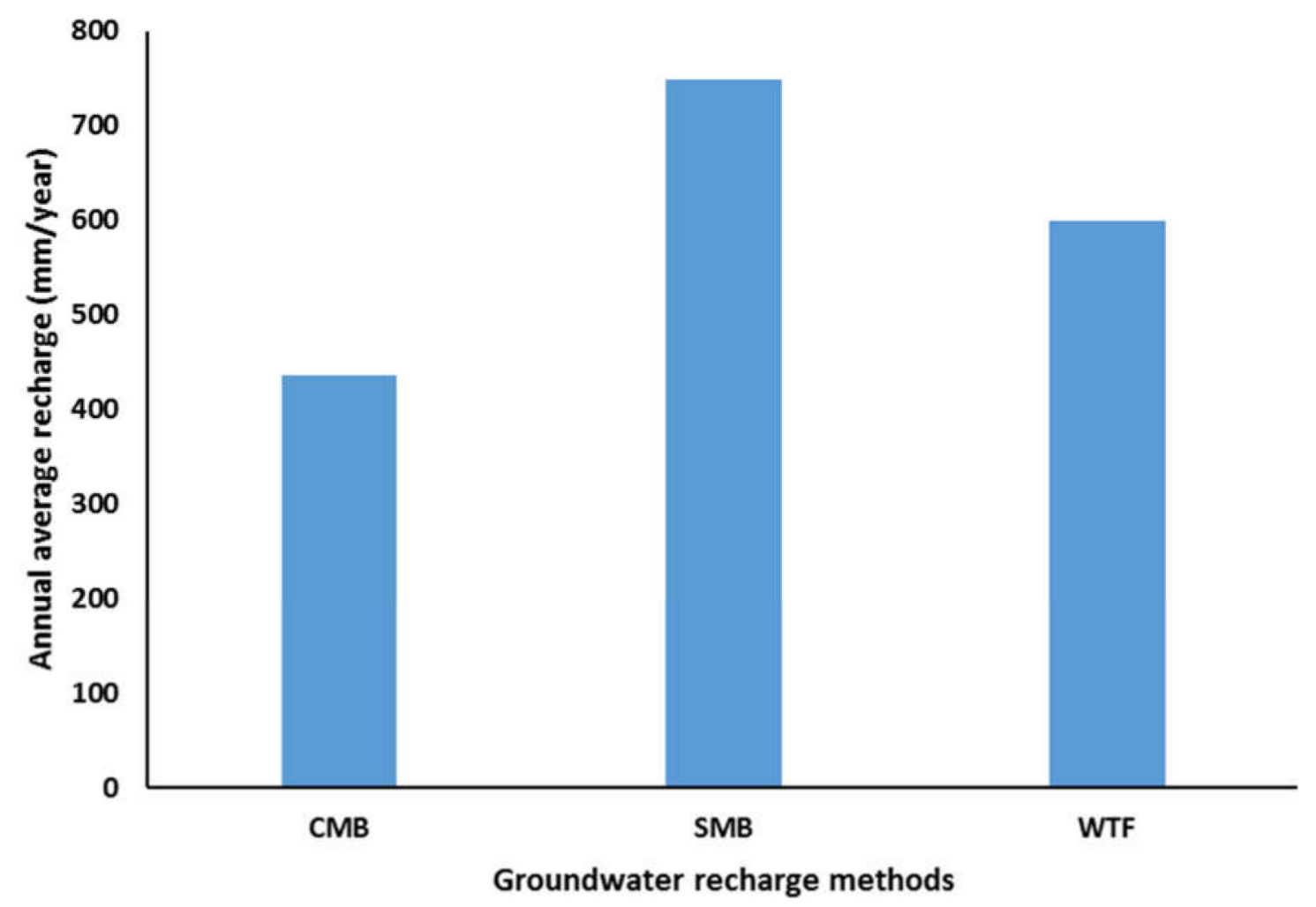

Figure 9. Comparison of results of different groundwater recharge estimation methods.

\subsection{Conceptual Hydrologic/Hydrogeologic Model and Sources of Recharge to the Springs}

The conceptual hydrogeologic model was developed to infer the groundwater flow system and to indicate sources of water for seasonal springs and high-discharge springs. This model was developed based on the integration of geological, geomorphological, hydro(geo)logical, and hydrochemical observations. The sources of water for the most upstream part of the Infranz River are multiple low-discharge and seasonal springs. The major sources of water for the Infranz river, however, are the Areke, Lomi, Tikur Wuha, and twin Infranz high-discharge springs. The area downstream and occasionally upstream from the high-discharge springs is rich with wetlands (Figure 5). The undulating surface, which is a characteristic of the area, also governs the surface water and local seepage flows.

From lithologic logs of drilled boreholes, a geological study [24], and field observations, less permeable Tertiary rhyolite has been identified under the recent Quaternary volcanics. This indicates that the older Quaternary basalt pinches out and the Tertiary Formation, consisting of less permeable rhyolite, appears immediately underneath the recent Quaternary volcanics (Figure 10). The spring occurrences are thought to be linked to geological and geomorphological features: the Tertiary rhyolite, which is less pervious than the overlying Quaternary basalts together with the local topographic slope break, is perching up the groundwater, resulting in contact springs. Based on topography and geologic 
data, a geologic cross-section was developed in a S-N direction, in which the potential groundwater flow lines are represented (Figure 9). As was shown by [15], based on chemical and isotopic data of a larger study area, comprising the Infranz catchment, the springs are locally recharged. As can be inferred from the cross-section in Figure 10 and from the geological map in Figure 2, the low-permeable Tertiary volcanics are outcropping in the area downstream of the major springs and are underlying in the wetland area. It is clear that the wetlands are mainly sustained by these springs. Based on the above principle, the local and sub-regional (at catchment scale) flow lines are outlined as indicated in Figure 10. The local flow lines (blue short arrows) discharge at seasonal springs/seepages that are influenced by climatic effects and become dry in the dry season and sources of water for seasonal springs, whereas the regional flow lines (long arrows in Figure 10) are less affected by climatic variables and are sources of water for perennial and high-discharge springs, the river, and wetlands.

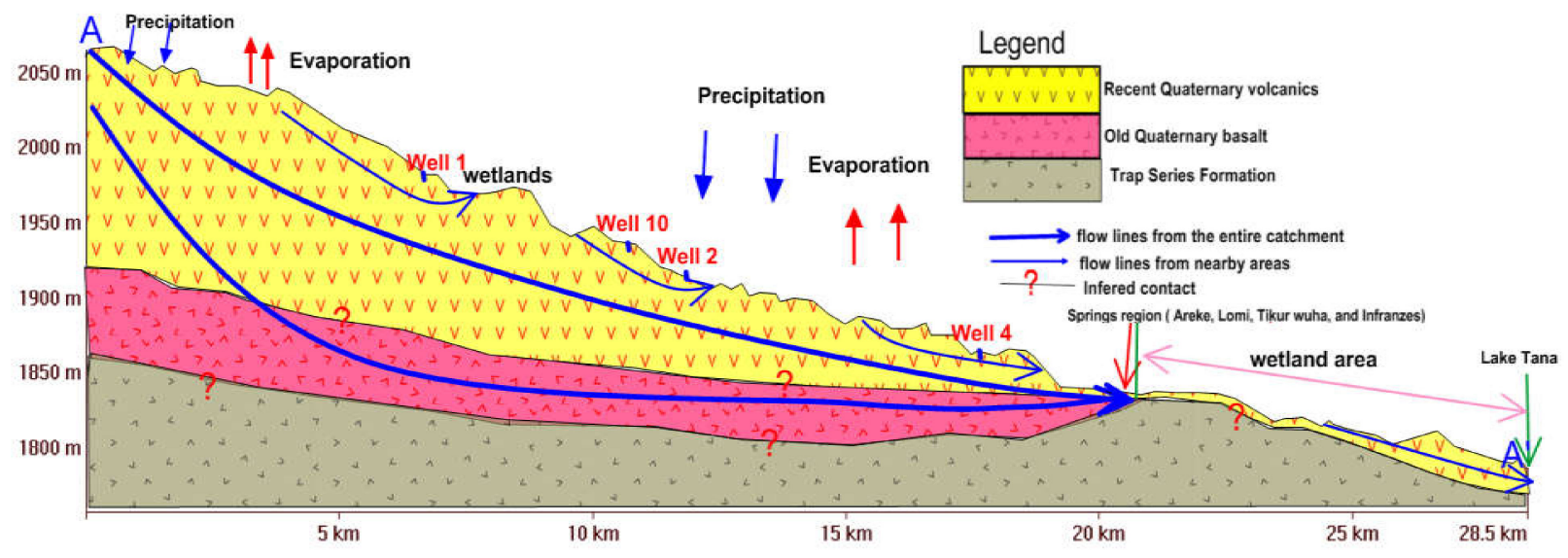

Figure 10. Schematic conceptual model of groundwater flow and circulation in the Infranz catchment, Lake Tana basin (location of cross-section A-A1 in Figure 2).

All collected data concerning springs, streams, wetlands, and their persistence and discharges, groundwater levels, and well discharges and recharge, were integrated to draw conclusions on how the hydrological system is functioning.

\section{Conclusions}

The schematic cross-section and flow lines in the conceptual model show that the springs emerge from the highly pervious young Quaternary basaltic formation, at the point of contact with the underlying lower-permeability Tertiary volcanic rocks. Local shallow flow systems discharge into seasonal springs and stream, while a regional flow system (within the Infranz catchment) sustains the high-discharge springs and downstream perennial Infranz River. The recharge area of these high-discharge springs covers the whole catchment. The specific geological conditions of the Infranz catchment, along with the highly vesicular and fractured scoriaceous young Quaternary basalts, and the typical geomorphology with the closed depressions surrounded by the low basalt ridges, create favorable conditions for high groundwater recharge. It was deduced by employing CMB, SMB, and WTF methods that $436-748 \mathrm{~mm} /$ year or $30 \%-51 \%$ of annual rainfall is recharging the groundwater. The comparable results may show the effectiveness of the methods for estimating recharge in specific geological, hydrogeological, geomorphological, and hydro-climatic areas. The range of the values is attributed to the possible uncertainties that are pertinent to some deviation from assumptions of each method, measurement errors, and spatial heterogeneity. The high-discharge springs are discharging about $8 \%-13 \%$ of this total recharge. Recharge over the catchment is thus more than sufficient to sustain the high-discharge springs. These exceptionally high recharge percentages may be expected in other areas with comparable geology and geomorphology 
Author Contributions: Conceptualization, F.N., A.S.B., A.Y., M.V.C. and K.W.; methodology, F.N., A.Y., and A.S.B.; software, F.N., A.S.B., A.Y. and M.V.C.; validation, F.N., A.S.B. and A.Y.; formal analysis, F.N., K.W. and M.V.C.; investigation, F.N., A.Y., A.S.B., K.W. and M.V.C.; writing-original draft preparation, F.N., A.Y., A.S.B and K.W.; writing-review and editing, F.N., A.Y., A.S.B., M.V.C.; and K.W; visualization, F.N., A.S.B., A.Y. and M.V.C.; supervision, K.W.; project administration, F.N. and K.W.; funding acquisition, F.N. and K.W. All authors have read and agreed to the published version of the manuscript.

Funding: This research was funded by the Belgian Flemish Inter University Council University Development Cooperation VLIR-UOS.

Acknowledgments: The authors are grateful to the Blue Nile Water Institute of Bahir Dar University for the financial and logistic support for the field work conducted in 2012 and 2013 . We also thank the Flemish Interuniversity Council (VLIR-UOS) funded TEAM-Tana Geo-hydro project for financial and logistic support for the fieldwork conducted from 2015-2018 and data analysis. Last but not least thanks to Mr Wubneh Belete, who provided GIS shapefiles of the project area.

Conflicts of Interest: The authors declare no conflict of interest. The funders have no role in the design of the study; in the collection, analysis, or interpretation of the data; in writing the manuscript, or in the decision to publish the results.

\section{References}

1. Jakeman, A.J.; Barreteau, O.; Rinaudo, R.J.H.J. Integrated Groundwater Management Concepts. Jakeman, A.J., Barreteau, O., Rinaudo, R.J.H.J., Ross, A., Eds.; Springer Nature: Berlin Heidelberg, Germany, 2016; ISBN 9783319235752.

2. Melesse, A.M.; Abtew, W.; Setegn, S.G. Nile River Basin: Ecohydrological challenges, climate change and hydropolitics. Springer: Berlin, Germany, 2013; pp. 1-718.

3. Kebede, S. Groundwater in Ethiopia: Features, numbers and opportunities; Springer-Verlag: Berlin, Germany, 2012; ISBN 9783642303906.

4. Freeze, R.A.; Cherry, J.A. Groundwater, 1st ed.; Prentice Hall: Englewood Cliffs, NJ, USA, 1979.

5. De Vries, J.J.; Simmers, I. Groundwater recharge: An overview of processes and challenges. Hydrogeol. J. 2002, 10, 5-17. [CrossRef]

6. Rushton, K.R.; Ward, C. The estimation of groundwater recharge. J. Hydrol. Eng. 1979, 41, 345-361. [CrossRef]

7. Todd, D.K.; Mays, L.W. Groundwater Hydrology, 3rd ed.; John Wiley \& Sons Inc.: Hoboken, NJ, USA, 2005; ISBN 0-471-45254-8.

8. Demlie, M. Assessment and estimation of groundwater recharge for a catchment located in highland tropical climate in central Ethiopia using catchment soil - water balance ( SWB ) and chloride mass balance ( CMB ) techniques. Env. Earth Sci 2015, 74, 1137-1150. [CrossRef]

9. Kulkarni, H.; Deolankar, S.B.; Lalwani, A.; Joseph, B.; Pawar, S. Hydrogeological framework of the Deccan basalt groundwater systems, west-central India. Hydrogeol. J. 2000, 8, 368-378. [CrossRef]

10. Jefferson, A.; Grant, G.; Rose, T. Influence of volcanic history on groundwater patterns on the west slope of the Oregon High Cascades. Water Resour. Res. 2006, 42, 1-15. [CrossRef]

11. Nigate, F. Investigating the Hydrogeological System of the Lake Tana Basin in the Northwestern Highlands of Ethiopia (the Upper Blue Nile). Ph.D. Thesis, Ghent University, Ghent, Belgium, 2019.

12. Peterson, F.L. Water Development on Tropic Volcanic Islands-Type Example: Hawaii. Groundwater 1972, 10, 18-23. [CrossRef]

13. Tropics Consulting Engineers. Bahir Dar Town Water Supply and Sanitation Project Feasibility Study. Report, Bahir Dar; Tropics Consulting Engineers P.L.C.: Addis Ababa, Ethiopia, 2012.

14. Abiye, T.A.; Kebede, S. The role of geodiversity on the groundwater resource potential in the upper Blue Nile River Basin, Ethiopia. Environ. Earth Sci. 2011, 64, 1283-1291. [CrossRef]

15. Nigate, F.; Van Camp, M.; Kebede, S.; Walraevens, K. Hydrologic interconnection between the volcanic aquifer and springs, Lake Tana basin on the Upper Blue Nile. J. African Earth Sci. 2016, 121. [CrossRef]

16. Awintis, J. Hydrogeological Study of the Infranz Catchment in Lake Tana basin, Ethiopia. Master's Thesis, Ghent University, Ghent, Belgium, 2017.

17. Van Landtschoote, A. Hydrogeological investigation and recharge estimation of Gumera river catchment in Lake Tana basin, northern Ethiopia. Master's Thesis, Ghent University, Ghent, Belgium, 2017.

18. Dessie, M.G. Hydrogeological investigation and groundwater recharge estimation of the Rib river catchment, Lake Tana Basin, upper Blue Nile, Ethiopia, MSc. Thesis, Ghent University, Ghent, Belgium, 2017. 
19. Nigate, F.; Ayenew, T.; Belete, W.; Walraevens, K. Overview of the Hydrogeology and Groundwater Occurrence in the Lake Tana Basin. In Social and Ecological System Dynamics: Characteristics, Trends, and Integration in the Lake Tana Basin, Ethiopia; Stave, K., Goshu, G., Aynalem, S., Eds.; Springer: Cham, Switzerland, 2017; pp. 77-91. ISBN 9783319457550.

20. Kebede, S.; Travi, Y.; Alemayehu, T.; Ayenew, T. Groundwater recharge, circulation and geochemical evolution in the source region of the Blue Nile River, Ethiopia. Appl. Geochemistry 2005, 20, 1658-1676. [CrossRef]

21. Kebede, S.; Admasu, G.; Travi, Y. Isotopes in environmental and health studies estimating ungauged catchment flows from Lake Tana floodplains, Ethiopia: An isotope hydrological approach. Isotopes Environ. Health Stud. 2011, 47, 37-41. [CrossRef]

22. Hadush, G. Groundwater Contribution and Recharge Estimation in the Upper Blue Nile flows, Ethiopia. Master's Thesis, ITC, Enschede, The Netherlands, 2008.

23. Mengistu, S. Numerical Groundwater Flow Modeling of the Lake Tana Basin, Upper Nile, Ethiopia. Ph.D. Thesis, Addis Ababa University, Addis Ababa, Ethiopia, 2010.

24. Ministry of water resources. Detailed groundwater investigation E monitoring in Tana and Beles basin; Ministry of water resources: Addis Ababa, Ethiopia, 2013.

25. SMEC. Hydrological study of the Tana-Beles basin: Groundwater investigation; Ministry of water, Irrigation and energy: Addis Ababa, Ethiopia, 2008.

26. Mamo, S. Integrated Hydrological and Hydrogeological System Analysis of the Lake Tana Basin, Northwestern Ethiopia. Ph.D Thesis, Addis Ababa University, Addis Ababa, Ethiopia, 2015.

27. Kebede, S.; Travi, Y.; Alemayehu, T.; Marc, V. Water balance of Lake Tana and its sensitivity to fluctuations in rainfall, Blue Nile basin, Ethiopia. J. Hydrol. 2006, 316, 233-247. [CrossRef]

28. Abbate, E.; Bruni, P.; Ferretti, M.P.; Delmer, C.; Laurenzi, M.A.; Hagos, M.; Bedri, O.; Rook, L.; Sagri, M.; Libsekal, Y. The East Africa Oligocene intertrappean beds: Regional distribution, depositional environments and Afro/Arabian mammal dispersals. J. African Earth Sci. 2014, 99, 463-489. [CrossRef]

29. Ethiopian Institute of Geological Surveys. Explanation of Geological Map of Ethiopia; Geological Survey of Ethiopia: Addis Ababa, Ethiopia, 1996.

30. Kieffer, B.; Arndt, N.; Bastien, F.; Bosch, D.; Pecher, A.; Yirgu, G.; Ayalew, D.; Weis, D.; Jerram, D.A.; Keller, F.; et al. Flood and Shield Basalts from Ethiopia: Magmas from the African Superswell. J. Petrol. 2004, 45, 793-834. [CrossRef]

31. Prave, A.R.; Bates, C.R.; Donaldson, C.H.; Toland, H.; Condon, D.J.; Mark, D.; Raub, T.D. Geology and geochronology of the Tana Basin, Ethiopia: LIP volcanism, Super eruptions and Eocene-Oligocene environmental change. Earth Planet. Sci. Lett. 2016, 443, 1-8. [CrossRef]

32. Ministry of Water Resources. BCEOM Abay River Basin integrated master plan, main report. Ministry of Water Resources: Addis Ababa, Ethiopia, 1999.

33. Tóth, J. A Theoretical Analysis of Groundwater Flow in Small A Theoretical Analysis of Groundwater Flow in Small Drainage Basins. J. Geophys. Res. 1963, 68, 4795-4812. [CrossRef]

34. Lerner, D.N.; Issa, A.S.; Simmers, I. Groundwater Recharge: A guide to Understanding and Estimating Natural Recharge; American Society of Agronomy: Madison, WI, USA, 1990.

35. Meinzer, O.E. Outline of ground-water hydrology. US Geol. Surv. Water Supply Pap. 1923, 494.

36. Wood, W.W. Use and misuse of the chloride mass balance method in estimating in groundwater recharge. Ground Water 1999, 37, 2-3. [CrossRef]

37. Healy, R.W. Estimating Groundwater Recharge; Cambridge University press: Cambridge, CA, USA, 2010; ISBN 978-0-511-79768-2.

38. Eriksson, E.; Khunakasem, V. Chloride concentrations in groundwater, recharge rate and rate of deposition of chloride in the Israel coastal plain. J. Hydrol. 1969, 7, 178-197. [CrossRef]

39. Ting, C.; Kereh, T.; Liao, C. Estimation of groundwater recharge using the chloride mass-balance method, Pingtung Plain, Taiwan. Hydrogeol. J. 1998, 6, 282-292. [CrossRef]

40. Rushton, K.R.; Eilers, V.H.M.; Carter, R.C. Improved soil moisture balance methodology for recharge estimation. J. Hydrol. 2006, 318, 379-399. [CrossRef]

41. Thornthwaite, C.W.; Mather, J.R. Instructions and Tables for Computing Potential Evapotranspiration and Water Balance. Publ. Climatol. 1957, 10, 183-311.

42. Crabtree, R.W.; Trudgill, S.T. Hillslope hydrochemistry and stream response on a wooded, permeable bedrock: The role of stemflow. J. Hydrol. 1985, 80, 161-178. [CrossRef] 
43. Steenhuis, T.S.; Van Der Molen, W.H. The TM procedure as a simple engineering method to predict recharge. J. Hydrol. 1986, 84, 221-229. [CrossRef]

44. Dripps, W.R.; Bradbury, K.R. A simple daily soil-water balance model for estimating the spatial and temporal distribution of groundwater recharge in temperate humid areas. Hydrogeol. J. 2007, 15, 433-444. [CrossRef]

45. Maréchal, J.C.; Dewandel, B.; Ahmed, S.; Galeazzi, L.; Zaidi, F.K. Combined estimation of specific yield and natural recharge in a semi-arid groundwater basin with irrigated agriculture. J. Hydrol. 2006, 329, 281-293. [CrossRef]

46. Sophocleous, M.A. Combining the soil water balance and water-level fluctuation methods to estimate natural groundwater recharge: Practical aspects. J. Hydrol. 1991, 124, 229-241. [CrossRef]

47. Allen, R.G.; Pereira, L.S.; Raes, D.; Smith, M.; Ab, W. Crop Evapotranspiration - Guidelines for Computing Crop Water Requirements; FAO Irrigation and drainage paper 56; FAO: Rome, Italy, 1998; pp. 1-15.

48. Healy, R.W.; Cook, P.G. Using groundwater levels to estimate recharge. Hydrogeol. J. 2002, 10, 91-109. [CrossRef]

49. Moon, S.K.; Woo, N.C.; Lee, K.S. Statistical analysis of hydrographs and water-table fluctuation to estimate groundwater recharge. J. Hydrol. 2004, 292, 198-209. [CrossRef]

50. Crosbie, R.S.; Binning, P.; Kalma, J.D. A time series approach to inferring groundwater recharge using the water table fluctuation method. Water Resour. Res. 2005, 41, 1-9. [CrossRef]

51. Jepsen, D.H.; Athearn, M.J. A General Geological Map of the Blue Nile River Basin, Ethiopia $(1: 1,000,000)$. Department of Water. Resources: Addis Ababa, Ethiopia, 1961.

52. Chorowicz, J.; Collet, B.; Bonavia, F.F.; Mohr, P.; Parrot, J.F.; Korme, T. The Tana basin, Ethiopia: Intra-plateau uplift, rifting and subsidence. Tectonophysics 1998, 295, 351-367. [CrossRef]

53. Sewnet, A. Land use/ cover change at Infranz watershed, Northwestern Ethiopia. J. Landsc. Ecol. 2015, 8, 69-83. [CrossRef]

54. Edmunds, W.M.; Darling, W.G.; Kinniburgh, D.G.; Kotoub, S.; Mahgoub, S. Sources of recharge at Abu Delaig, Sudan. J. Hydrol. 1992, 131, 1-24. [CrossRef]

55. Edmunds, W.M.; Gaye, C.B. Estimating the spatial variability of groundwater recharge in the Sahel using chloride. J. Hydrol. 1994, 156, 47-59. [CrossRef]

56. Ayenew, T.; Demlie, M.; Wohnlich, S. Hydrogeological framework and occurrence of groundwater in the Ethiopian aquifers. J. African Earth Sci. 2008, 52, 97-113. [CrossRef]

57. Belcher, W.R.; Elliott, P.E.; Geldon, A.L. Hydraulic-Property Estimates for Use With a Transient Ground-Water Flow Model of the Death Valley Regional Ground-Water Flow System, Nevada and California; USGS: Reston, VA, USA, 2001.

58. Walker, D.; Parkin, G.; Gowing, J.; Haile, A.T. Development of a Hydrogeological Conceptual Model for Shallow Aquifers in the Data Scarce Upper Blue Nile Basin. Hydrology 2019, 6, 43. [CrossRef]

59. Hagedorn, B.; El-Kadi, A.I.; Mair, A.; Whittier, R.B.; Ha, K. Estimating recharge in fractured aquifers of a temperate humid to semiarid volcanic island (Jeju, Korea) from water table fluctuations, and Cl, CFC-12 and 3H chemistry. J. Hydrol. 2011, 409, 650-662. [CrossRef]

60. Hahn, J.; Lee, Y.; Kim, N.; Hahn, C.; Lee, S. The groundwater resources and sustainable yield of Cheju volcanic island, Korea. Environ. Geol. 1997, 33, 43-53. [CrossRef]

61. Nicolas, W.D.; Shade, P.J.; Hunt, C.D.J. Summary of the Oahu, Hawaii, Regional Aquifer-System Analysis; U.S. Geological Survey: Denver, CO, USA, 1996.

(C) 2020 by the authors. Licensee MDPI, Basel, Switzerland. This article is an open access article distributed under the terms and conditions of the Creative Commons Attribution (CC BY) license (http://creativecommons.org/licenses/by/4.0/). 